\title{
Administrative and Legal Status of Public Administration, which Carries out Administrative and Legal Regulation in Ukrainian Space Defense
}

\author{
Artem Zubko \\ Ph.D. student, Research Institute of Public Law (Kyiv, Ukraine) \\ E-mail: zubko18@gmail.com
}

\begin{abstract}
The key term of space law "peaceful uses" of outer space loses its meaning in an increasingly militarized space. A few decades ago, national defense strategies envisaged in the term "space defense" mainly the information security provided by satellites. However, after recent tests against China's satellite weapons, there was a need for a rethinking and other meaningful definition of the notion of "space defense," and the administrative and legal status of a public administration that carries out administrative and legal regulation in the sphere of Ukrainian Space Defense. The purpose of the paper is to determine, based on the research and analysis of the positions of Ukrainian scholars, the foundations of legislation, the administrative and legal status of the public administration, which carries out administrative and legal regulation in Ukrainian Space Defense.

Keywords: Ukrainian Space Defense; space law; anti-satellite weapons; administrative-legal status; public administration.
\end{abstract}

\section{Адміністративно-правовий статус публічної адміністрації, яка здійснюс адміністративно-правове регулювання у сфері космічної оборони України}

\section{Зубко, Артем Олександрович}

Здобувач наукового ступеня кандидата юридичних наук

Науково-дослідного інституту публічного права

(Київ, Україна)

\begin{abstract}
Ключовий термін космічного права «використання космічного простору в мирних цілях» втрачає сенс в усе більш мілітаризованому космосі. Ще кілька десятиліть тому національні стратегії оброни передбачали в терміні «космічна оборона» головним чином інформачійний захист, щуо забезпечується супутниками. Але після нещодавніх випробувань протисупутникової зброї Китаєм, виникла необхідність переосмислення та іншого змістовного визначення поняття «космічна оборона», та адміністративно-правовий статус публічної адміністрації, яка здійснює адміністративно-правове регулювання у сфері космічної оброни України. Мета статті полягає в
\end{abstract}

(C) Zubko, Artem, 2018 
тому, щуоб на базі дослідження та аналізу позицій українських вчених-юристів, основ законодавства, визначити адміністративно-правовий статус публічної адміністрації, яка здійснює адміністративно-правове регулювання у сфері космічної оброни Украӥни.

Ключові слова: космічна оборона Украӥни; протисупутникова зброя; космічне право; публічна адміністрація; правовий статус; адміністративно-правовий статус.

Received: January 3, 2018; accepted: February 5, 2018

Advanced Space Law, Volume 1, 2018: 98-107.

https://doi.org/10.29202/asl/2018/1/12

\section{Постановка проблеми}

В статті Павле Кілібарда «Мілітаризація космічного простору та Конвенція про відповідальність», що надрукована в авторитетному науковому журналі «Air and Space Law» (Нідерланди) визначається головний тезис нашої статті [Kilibarda, 2015]. A саме, ключовий термін космічного права «використання космічного простору в мирних цілях» втрачає сенс в усе більш мілітаризованому космосі. Ще кілька десятиліть тому національні стратегії оброни передбачали в терміні «космічна оборона» головним чином інформаційний захист, що забезпечується супутниками. Але після нещодавніх випробувань протисупутникової зброї Китаєм, виникла необхідність переосмислення та іншого змістовного визначення поняття «космічна оборона», та адміністративно-правовий статус публічної адміністрації, яка здійснює адміністративно-правове регулювання у сфері космічної оброни України. Зазначмо, що протисупутникову зброю, що призначена для знищення космічних апаратів, що використовуються в навігаційних і розвідувальних цілях, вже мають Китай, Росія, США, Ізраіль та Індія. Над розробкою протисупутникової зброї працюють Німеччина, Франція та Велика Британія.

Сили безпеки та оборони, які існували в Україні в березні 2014 року, не змогли ефективно реагувати на зовнішні виклики. Відбулося захоплення Криму та розпочався перманентний конфлікт на Сході України. 3 того часу Україна здійснила значний прогрес в розбудові своїх оборонних спроможностей. Тим не менше, цих зусиль недостатньо для подолання нинішніх та майбутніх загроз для країни. Ми взяли рух на побудову оборонної організації відповідно до стандартів НАТО. Одним з ключових принципів, на яких грунтується ефективна організація системи оборони країн НАТО є чітко визначені ролі, обов'язки та повноваження. Усе вищевикладене підкреслює актуальність дослідження адміністративно-правового статусу публічної адміністрації, яка здійснює адміністративно-правове регулювання у сфері космічної оборони України. Мета статті полягає в тому, щоб на базі дослідження та аналізу позицій українських вчених-юристів, основ законодавства, визначити адміністративно-правовий статус публічної адміністрації, яка здійснює адміністративно-правове регулювання у сфері космічної оброни України.

\section{Виклад основних положень}

У перекладі з латини status означає «положення, стан у будь-якій ієрархії, структурі, системі» [Білодід, 1976]. Згідно з тлумачним словником української мови поняття «ста- 
тус» — це певний стан чого-небудь [Яременко \& Сліпушко, 2008: 420]. Теоретики права розкривають правовий статус людини як юридично закріплене становище людини в суспільстві, відповідно до якого фізична особа як суб’єкт права вступає у правовідносини, координує свою діяльність і поведінку в суспільстві [Скакун, 2011: 60].

Станіслав Гусарєв переконаний, що феномен правового статусу особистості визначає «співвідношення особистості та права, за допомогою якого держава окреслює для суб'єкта межі можливої діяльності, його становище стосовно інших суб'єктів і залежно від індивідуальних або типових ознак, які властиві суб'єктові, у праві відбиваються повнота правового становища особистості, його певна уніфікація або обмеження» [Гусарєв, 2000: 41].

Таким чином, правовий статус — це провідна категорія права, яка за допомогою конкретних правових елементів визначає становище суб'єкта у певних правовідносинах.

Щодо адміністративно-правового статусу, то Михайло Цуркан переконаний, що правовий статус суб'єктів публічної адміністрації - це закріплена в нормативних актах сукупність взаємозалежних і взаємозумовлених функціональних інструментів (компетенція) і статичних якостей (цільовий, організаційно-структурний компоненти), необхідних для повноцінної участі цих суб'єктів у адміністративно-правових відносинах, забезпечення досягнення соціального ефекту [Цуркан, 2010: 52].

Марта Горбач наголошує, що за змістом адміністративно-правовий статус суб'єктів адміністративного права — це взаємопов'язаний комплекс юридично закріплених адміністративних завдань (функцій), адміністративних прав та обов’язків, установлених на основі адміністративно-правових норм, а також адміністративно відповідального позитивного (реалізується владними суб'єктами адміністративного права) і негативного характеру (накладається на суб'єктів адміністративного права), що мають загальний, універсальний характер для всіх однорідних учасників адміністративно-правових відносин. Загалом, з позиції Горбач, адміністративно-правовий статус суб'єктів адміністративного права як правова категорія — це система однорідних адміністративно-правових норм, які засвідчують факт формально-юридичного існування суб'єкта адміністративного права, а також здійснюють визначення його правового становища у взаємодії з іншими суб'єктами права, державою та з суспільством у цілому [Горбач, 2017: 43].

Ярина Токар-Балаж розкриває адміністративно-правовий статус як спеціальний правовий статус, який характеризує особу через іiі права, обов'язки та відповідальність у якості суб’єкта адміністративного права і забезпечує участь в суспільних відносинах, які виникають у зв'язку із забезпеченням суб'єктами публічної влади прав і свобод фізичних осіб, при взаємодії органів публічної влади з інституціями громадянського суспільства, а також опосередковано у відносинах, які пов'язані зі сферою публічного адміністрування об'єктів державної та комунальної власності, а інколи - у відносинах, які мають місце у внутрішньо-організаційній діяльності органів публічної влади [Токар-Балаж, 2015: 85].

Олександр Музичук під правовим статусом суб'єкта адміністративно-правових відносин визначає систему закріплених у нормативно-правових актах ознак, які визначають його роль, місце та призначення в системі правовідносин, указують на його відмінність від інших суб’єктів і порядок взаємовідносин між ними [Музичук, 2008: 320].

На думку Тетяни Коломоєць, адміністративно-правовий статус — це сукупність суб'єктивних прав і обов'язків закріплених нормами адміністративного права за певним органом. Водночас обов'язковою ознакою набуття суб'єктом адміністративно-правово- 
го статусу є наявність у нього конкретних суб'єктивних прав і обов'язків, що реалізуються у рамках як адміністративних правовідносин, так і поза ними [Адміністративне право, 2011: 64].

Таким чином, адміністративно-правовий статус - це провідна категорія адміністративного права, що за допомогою адміністративно-правових норм визначає становище суб'єкта права в адміністративно-правових відносинах та розкриває особливості його взаємовідносин з іншими суб'єктами права.

Неможливо розкрити зміст правового статусу без розкриття його юридичних складових. 3 позиції Антона Панчишина, до структури правового статусу як інтегрованого поняття належать: правові норми, що визначають статус; основні права, свободи, законні інтереси та обов'язки; правосуб'єктність; правові принципи; громадянство; гарантії прав і свобод; юридична відповідальність; правовідносини загального типу [Панчишин, 2010: 95-96]. В свою чергу, теоретик Анатолій Колодій визначає такі його елементи: статусні правові норми і правові відносини; суб'єктивні права, свободи і юридичні обов'язки; громадянство; правові принципи і юридичні гарантії; законні інтереси; правосуб'єктність; юридична відповідальність. Деякі автори як елементи правового статусу розглядають правове зобов'язання, законність, правопорядок, правосвідомість, гуманізм, справедливість [Загальна теорія, 1999: 54].

Щодо адміністративного права, то Олексій Гумін і Свген Пряхін, до елементів адміністративного статусу відносять правосуб'єктність, права, обов'язки та юридичну відповідальність. Не всі права, закріплені в законодавстві, характеризують адміністративно-правовий статус. До них відносяться лише ті, що передбачені нормами адміністративного права та реалізуються у взаємовідносинах 3 органами публічної влади, оскільки адміністративно-правові відносини існують тільки там, де один із суб'єктів $є$ суб'єктом владних повноважень. Аналогічно слід говорити і про обов'язки. Адміністративно-правовий статус характеризують лише ті, що зумовлюються виникненням взаємовідносин з органами публічної влади. Для національного законодавства залишається проблемним, що в нормативно-правових актах переважно йдеться не окремо про права та обов’язки, а про «повноваження» [Гумін \& Пряхін, 2014: 37].

В свою чергу, Марта Горбач переконана, що основними юридичними елементами адміністративно-правового статусу публічних осіб є завдання (функції), адміністративні обов'язки та відповідні права з метою публічного виконання законодавства. При цьому, стрижнем адміністративно-правового статусу є адміністративні обов'язки та права, а адміністративна відповідальність може бути вагомим додатковим елементом їхнього статусу. До додаткового елемента адміністративно-правового статусу публічної адміністрації належать порядок і підстави виникнення та припинення адміністративної правосуб'єктності, що включають у себе адміністративно-правові аспекти створення та публічної легалізації публічних осіб [Горбач, 2017: 170].

Таким чином, до елементів адміністративно-правового статусу публічної адміністрації, яка здійснює адміністративно-правове регулювання у сфері оборонно-промислового комплексу належать:

1. Обов’язки та права публічної адміністрації;

2. Завдання та функції публічної адміністрації, а також засади регулювання космічною оборою України;

3. Адміністративна відповідальність у сфері адміністративно-правового регулювання космічною обороною України. 
Розкриваючи адміністративно-правовий статус публічної адміністрації, яка здійснює адміністративно-правове регулювання у сфері космічної оборони України, необхідно визначитись 3 терміном «публічна адміністрація». Вадим Авер'янов «публічну адміністрацію» визначив як сукупність органів виконавчої влади та органів виконавчого самоврядування, підпорядкованих політичній владі, які забезпечують виконання закону та здійснюють інші публічно-управлінські функції [Адміністративне право, 2004: 76]. Валерій Колпаков трактує термін «публічна адміністрація» як систему організаційно-структурних утворень, які на законних підставах набули владних повноважень для їх реалізації в публічних інтересах [Колпаков, 2008: 57].

3 позиції Тетяни Кравцової та Анастасії Солонар, публічна адміністрація — це певним чином побудована система органів державної виконавчої влади та виконавчих органів місцевого самоврядування, підприємства, установи, організації та інші суб'єкти, наділені адміністративно-управлінськими функціями, які діють з метою забезпечення як інтересів держави, так і інтересів суспільства в цілому. При цьому їй притаманні властивості, які відрізняють іiі від інших державних утворень і які можна побачити у визначенні цього поняття. Діяльність усіх державних органів базується на певних принципах, не є виключенням і публічна адміністрація, вона також діє відповідно до певних принципів - верховенства права, гуманізму, законності, демократизму, професійної компетентності, відповідальності тощо [Кравцова \& Солонар, 2010: 523].

Отже, публічна адміністрація, яка здійснює адміністративно-правове регулювання у сфері космічної оборони України — це комплекс публічних структур, які мають виконавчо-розпорядчі та організаційні повноваження щодо правового регулювання космічною обороною України з метою виконання політики держави в площині забезпечення національної безпеки та оборони.

Розкривши загальні категорії, необхідно розкрити саму ж систему органів, які здійснюють адміністративно-правове регулювання у сфері космічної оборони України.

Очолює сектор державної безпеки України Президент України, як Верховний Головнокомандувач Збройних сил України згідно зі статтею 106 Конституції України [Конституція України, 1996]. Тобто, в певній мірі він здійснює адміністративно-правове регулювання у сфері космічної оборони України. Прикладом такого регулювання є затвердження Концепції розвитку сектору безпеки і оборони України, яка визначає систему поглядів на розвиток безпекових та оборонних спроможностей України у середньостроковій перспективі, сформованих на основі оцінки безпекового середовища та фінансово-економічних можливостей держави, здійснених у рамках комплексного огляду сектору безпеки і оборони України [Про рішення Ради, 2016].

Необхідно вказати і про Раду національної безпеки і оборони України, яка відповідно до Конституції України є координаційним органом 3 питань національної безпеки і оборони при Президентові України. Функціями Ради національної безпеки і оборони України є: внесення пропозицій Президентові України щодо реалізації засад внутрішньої і зовнішньої політики у сфері національної безпеки і оборони; координація та здійснення контролю за діяльністю органів виконавчої влади у сфері національної безпеки і оборони у мирний час; координація та здійснення контролю за діяльністю органів виконавчої влади у сфері національної безпеки і оборони в умовах воєнного або надзвичайного стану та при виникненні кризових ситуацій, що загрожують національній безпеці України [Про Раду, 1998]. 
На виконання Концепції розвитку сектору безпеки і оборони України, затвердженої Указом Президента України від 14 березня 2016 р. № 92/2016 Кабінетом Міністрів України схвалена Стратегія розвитку оборонно-промислового комплексу України на період до 2028 року, що $є$ основою для розроблення нових та перегляду існуючих нормативно-правових актів (у тому числі державних цільових програм) у сфері розвитку та функціонування космічної оборони України [Про схвалення, 2018].

Неможливо говорити про адміністративно-правове регулювання у сфері космічної оборони без Міністерства оборони України (Міноборони), що $є$ центральним органом виконавчої влади, діяльність якого спрямовується і координується Кабінетом Міністрів України. Міноборони є головним органом у системі центральних органів виконавчої влади, який забезпечує формування та реалізує державну політику з питань національної безпеки у воєнній сфері, сфері оборони і військового будівництва у мирний час та особливий період. Міноборони є органом військового управління, у підпорядкуванні якого перебувають Збройні Сили. Міноборони є уповноваженим центральним органом виконавчої влади в галузі державної авіації [Про затвердження, 2014].

Безпосередньо Міністру Оборони України підпорядковується Управління інформаційних технологій, що належить до структури апарату Міністерства. Управління інформаційних технологій є відокремленим підрозділом Міністерства оборони України, який призначений для забезпечення формування та реалізації державної політики інформаційної безпеки і інформатизації, організації та координації заходів щодо впровадження новітніх інформаційних технологій, формування єдиного інформаційного простору Міністерства оборони, розробки концептуальних основ державної космічної політики в частині, пов'язаній зі створенням та використанням космічної техніки військового призначення, а також разом із Державним космічним агентством України - космічної техніки подвійного призначення (використання) [Управління, 2017].

Космічна оборона України грунтується на:

1. Законі України «Про космічну діяльність» [Закон України, 1996]. В Законі відсутнє поняття «космічна оборона». Але закон дає визначення близьких за змістом понять «інцидент», «надзвичайна подія», та «правила космічної діяльності». В Статті 3 Закону визначена мета космічної діяльності «створення та підтримка космічними засобами сучасного інформаційного простору держави» [Закон України, 1996]. Головною вимогою переходу України до стандартів НАТО, а також Стратегії розвитку оборонно-промислового комплексу України, є саме створення та підтримка сучасного інформаційного простору держави, що забезпечується в умовах сьогодення виключно космічними засобами.

2. Законі України «Про основи національної безпеки України». Закон визначає основні засади державної політики, спрямованої на захист національних інтересів і гарантування в Україні безпеки особи, суспільства i держави від зовнішніх i внутрішніх загроз в усіх сферах життедіяльності. [Про основи, 2003]

3. Законі України «Про державну підтримку космічної діяльності». У Статті 3 Закону метою державної підтримки космічної діяльності в Україні є збереження і подальший розвиток науково-технічного, технологічного та виробничого потенціалу космічної галузі як одного з факторів національної безпеки [Закон України, 2000].

4. Законі України «Про державну таємницю». Закон регулює суспільні відносини, пов'язані з віднесенням інформації до державної таємниці, засекречуванням, роз- 
секречуванням іiї матеріальних носіїв та охороною державної таємниці з метою захисту національної безпеки України [Закон України, 1994].

5. Законі України «Про державний контроль за міжнародними передачами товарів військового призначення та подвійного використання». Закон регулює діяльність, пов'язану з державним контролем за міжнародними передачами товарів військового призначення та подвійного використання, з метою забезпечення захисту національних інтересів України, дотримання нею міжнародних зобов'язань щодо нерозповсюдження зброї масового знищення та засобів ії доставки [Закон України, 2003].

Таким чином, систему органів, які здійснюють адміністративно-правове регулювання у сфері космічної оборони України становлять:

1. Президент України, як Верховний Головнокомандувач Збройних сил України;

2. Рада національної безпеки і оборони України, координаційний орган у сфері національної безпеки і оборони при Президентові України;

3. Кабінет Міністрів України, визначає державну політику у сфері оборони та є суб'єктом управління об'єктами державної власності в що працюють на космічну оборону України;

4. Міністерство оборони України та Міністерство економічного розвитку і торгівлі, що реалізують державну політику у сфері космічної оборони України;

5. Державне космічне агентство України, що забезпечує організацію космічної діяльність у сфері оборони та національної безпеки.

\section{Висновки}

Усе вищевикладене дає підстави вважати, що:

1. Аміністративно-правовий статус — це провідна категорія адміністративного права, що за допомогою адміністративно-правових норм визначає становище суб'єкта права в адміністративно-правових відносинах та розкриває особливості його взаємовідносин з іншими суб'єктами права;

2. До елементів адміністративно-правового статусу публічної адміністрації, яка здійснює адміністративно-правове регулювання у сфері оборонно-промислового комплексу належать: 1) обов'язки та права публічної адміністрації; 2) завдання та функції публічної адміністрації, а також засади регулювання оборонно-промислового комплексу; 3) адміністративна відповідальність у сфері адміністративно-правового регулювання космічною обороною України;

3. Публічна адміністрація, яка здійснює адміністративно-правове регулювання у сфері космічної оборони України — це комплекс публічних структур, які мають виконавчо-розпорядчі та організаційні повноваження щодо правового регулювання оборонно-промислового комплексу з метою виконання політики держави в площині забезпечення національної безпеки та оборони;

4. Систему органів, які здійснюють адміністративно-правове регулювання у сфері космічної оборони України становлять: Президент України (як Верховний Головнокомандувач Збройних сил України); Рада національної безпеки і оборони України (координаційний орган у сфері національної безпеки і оборони при Президентові України); Кабінет Міністрів України (визначає державну політику у сфері оборони та є суб'єктом управління об’єктами державної власності в обо- 
ронно-промисловому комплексі); Міністерства оборони України та Міністерство економічного розвитку і торгівлі (реалізують державну політику у сфері оборонно-промислового комплексу); Державне космічне агентство України (забезпечує організацію космічної діяльність у сфері оборони та національної безпеки).

\section{Література}

Адміністративне право Украӥни. Академічний курс. За редакцією Тетяни Коломоєць. Київ: Юрінком Інтер, 2011.

Адміністративне право Украӥни. Академічний курс у 2 m. За редакцією Вадима Авер'янова. Т. 1. Загальна частина. Київ: Юридична думка, 2004.

Білодід, І. Словник украӥнської мови: в 11 томах. Том 7. 1976. http://sum.in.ua/s/ pryznachennja

Горбач, Марта. Адміністративно-правовий статус суб’єктів адміністративного права: теорія $i$ практика. Дис... канд. юрид. наук: 12.00.07. НДІ публічного права. Київ. 2017. 202 с.

Гумін, Олексій, Пряхін, Євген. Адміністративно-правовий статус особи: поняття та структура. Наше право. 5, 2014: 35-37.

Гусарєв, Станіслав. Теоретичні аспекти забезпечення правового статусу особистості в Україні. Науковий вісник Дніпропетровського юридичного інституту МВС України. 1, 2000: 39-44.

Загальна теорія держави і права. За редакцією Володимира Копєйчикова. Національний педагогічний ун-т ім. М. П. Драгоманова. Київ: Юрінком Інтер, 1999.

Закон України «Про державну підтримку космічної діяльності», від 16.03.2000 р. № 1559-III. http://www.nkau.gov.ua/ua/legislation

Закон України «Про державну таємниџю» від 21.01.1994 p. № 3855-XII. http://www. nkau.gov.ua/ua/legislation

Закон України «Про державний контроль за міжнародними передачами товарів військового призначення та подвійного використання» від 20.02.2003 р. № 549$I V$. http://www.nkau.gov.ua/ua/legislation

Закон Украӥни «Про космічну діяльність» від 15.11.1996 p. № 502/96-BP. http://www. nkau.gov.ua/ua/legislation

Колпаков, Валерій. Адміністративна відповідальність (адміністративно-деліктне право). Київ: Юрінком Інтер, 2008.

Конституція України від 28 червня 1996 року. Відомості Верховної Ради. 30, 1996. Ст. 141.

Кравцова, Тетяна, Солонар, Анастасія. Поняття та принциии діяльності публічної адміністрації. Форум права. 4, 2010: 522-525.

Музичук, Олександр. Уточнення сутності категорії «правовий статус» суб'єкта адміністративно-правових відносин та його елементного складу. Форум права. 1, 2008: 316-321.

Панчишин, Антон. Поняття, ознаки та структура категорії «правовий статус». Часопис Київького університету права. 2, 2010: 95-98.

Про затвердження Положення про Міністерство оборони України : Постанова Кабінету Міністрів України від 26.11.2014 № 671. Офіційний вісник України. 97, 2014. 
Про Раду національної безпеки і оборони України: Закон України від 05.03.1998 № 183/98-ВР. Офіційний вісник Украӥни. 13, 1998.

Про основи національної безпеки України, від 19.06.2003 p. № 964-IV. http://www.nkau. gov.ua/ua/legislation

Про рішення Ради національної безпеки і оборони України від 4 березня 2016 року «Про

Концепцію розвитку сектору безпеки і оборони України». Затверджено Указом

Президента України від 14 березня 2016 року № 92/2016. Офіційний вісник України. 23, 2016. Ст. 898.

Про схвалення Стратегії розвитку оборонно-промислового комплексу України на період до 2028 року: схвалено розпорядженням Кабінету Міністрів України від 20 червня 2018 р. № 442-р. Урядовий кур ’єр. 121, 2018.

Скакун, О. Теорія прав і держава: підручник. Київ: Алерта. 2011.

Токар-Балаж, Ярина. Деякі питання визначення правового статусу особи у адміністративному праві. Наме право. 2, 2015: 81-85.

Управління інформаційних технологій. 2017. http://www.mil.gov.ua/ministry/strukturaaparatu-ministerstva/uit.html

Цуркан, Михайло. Правове регулювання публічної служби в Україні. Особливості судового розгляду спорів. Харків. 2010. С. 51-55.

Яременко, В., Сліпушко, О. Новий словник украӥнської мови: у 3 m. Київ: Аконіт. 2008.

Kilibarda, Pavle. The Militarization of Outer Space and the Liability Convention. Air and Space Law, Volume 40 Issue 3, 2015: 271-290.

\section{References}

Administratyvne pravo Ukrainy. Akademichnyi kurs. Za redaktsiieiu Tetiany Kolomoiets. Kyiv: Yurinkom Inter, 2011.

Administratyvne pravo Ukrainy. Akademichnyi kurs u 2 t. Za redaktsiieiu Vadyma Averianova. T. 1. Zahalna chastyna. Kyiv: Yurydychna dumka, 2004.

Bilodid, I. Slovnyk ukrainskoi movy: v 11 tomakh. Tom 7. 1976. http://sum.in.ua/s/pryznachennja Horbach, Marta. Administratyvno-pravovyi status sub 'iektiv administratyvnoho prava: teoriia i praktyka. Dys... kand. yuryd. nauk: 12.00.07. NDI publichnoho prava. Kyiv. 2017. $202 \mathrm{~s}$.

Humin, Oleksii, Priakhin, Yevhen. Administratyvno-pravovyi status osoby: poniattia ta struktura. Nashe pravo. 5, 2014: 35-37.

Husariev, Stanislav. Teoretychni aspekty zabezpechennia pravovoho statusu osobystosti v Ukraini. Naukovyi visnyk Dnipropetrovskoho yurydychnoho instytutu MVS Ukrainy. 1, 2000: 39-44.

Zahalna teoriia derzhavy i prava. Za redaktsiieiu Volodymyra Kopieichykova. Natsionalnyi pedahohichnyi un-t im. M. P. Drahomanova. Kyiv: Yurinkom Inter, 1999.

Zakon Ukrainy «Pro derzhavnu pidtrymku kosmichnoi diialnosti», vid 16.03.2000 r. № 1559III. http://www.nkau.gov.ua/ua/legislation

Zakon Ukrainy «Pro derzhavnu taiemnytsiu» vid 21.01.1994 r. № 3855-XII. http://www.nkau. gov.ua/ua/legislation

Zakon Ukrainy «Pro derzhavnyi kontrol za mizhnarodnymy peredachamy tovariv viiskovoho pryznachennia ta podviinoho vykorystannia» vid 20.02.2003 r. № 549-IV. http://www. nkau.gov.ua/ua/legislation 
Zakon Ukrainy «Pro kosmichnu diialnist» vid 15.11.1996 r. № 502/96-VR. http://www.nkau. gov.ua/ua/legislation

Kolpakov, Valerii. Administratyvna vidpovidalnist (administratyvno-deliktne pravo). Kyiv: Yurinkom Inter, 2008.

Konstytutsiia Ukrainy vid 28 chervnia 1996 roku. Vidomosti Verkhovnoi Rady. 30, 1996. St. 141.

Kravtsova, Tetiana, Solonar, Anastasiia. Poniattia ta pryntsypy diialnosti publichnoi administratsii. Forum prava. 4, 2010: 522-525.

Muzychuk, Oleksandr. Utochnennia sutnosti katehorii «pravovyi status» sub'iekta administratyvno-pravovykh vidnosyn ta yoho elementnoho skladu. Forum prava. 1, 2008: 316321.

Panchyshyn, Anton. Poniattia, oznaky ta struktura katehorii «pravovyi status». Chasopys Kyivskoho universytetu prava. 2, 2010: 95-98.

Pro zatverdzhennia Polozhennia pro Ministerstvo oborony Ukrainy : Postanova Kabinetu Ministriv Ukrainy vid 26.11.2014 № 671. Ofitsiinyi visnyk Ukrainy. 97, 2014.

Pro Radu natsionalnoi bezpeky i oborony Ukrainy: Zakon Ukrainy vid 05.03.1998 № 183/98VR. Ofitsiinyi visnyk Ukrainy. 13, 1998.

Pro osnovy natsionalnoi bezpeky Ukrainy, vid 19.06.2003 r. № 964-IV. http://www.nkau.gov. ua/ua/legislation

Pro rishennia Rady natsionalnoi bezpeky i oborony Ukrainy vid 4 bereznia 2016 roku "Pro Kontseptsiiu rozvytku sektoru bezpeky i oborony Ukrainy". Zatverdzheno Ukazom Prezydenta Ukrainy vid 14 bereznia 2016 roku № 92/2016. Ofitsiinyi visnyk Ukrainy. 23, 2016. St. 898.

Pro skhvalennia Stratehii rozvytku oboronno-promyslovoho kompleksu Ukrainy na period do 2028 roku: skhvaleno rozporiadzhenniam Kabinetu Ministriv Ukrainy vid 20 chervnia 2018 r. № 442-r. Uriadovyi kurier. 121, 2018.

Skakun, O. Teoriia prav i derzhava: pidruchnyk. Kyiv: Alerta. 2011.

Tokar-Balazh, Yaryna. Deiaki pytannia vyznachennia pravovoho statusu osoby u administratyvnomu pravi. Nashe pravo. 2, 2015: 81-85.

Upravlinnia informatsiinykh tekhnolohii. 2017. http://www.mil.gov.ua/ministry/struktura-aparatu-ministerstva/uit.html

Tsurkan, Mykhailo. Pravove rehuliuvannia publichnoi sluzhby v Ukraini. Osoblyvosti sudovoho rozghliadu sporiv. Kharkiv. 2010. S. 51-55.

Yaremenko, V., Slipushko, O. Novyi slovnyk ukrainskoi movy: u 3 t. Kyiv: Akonit. 2008.

Kilibarda, Pavle. The Militarization of Outer Space and the Liability Convention. Air and Space Law, Volume 40 Issue 3, 2015: 271-290. 